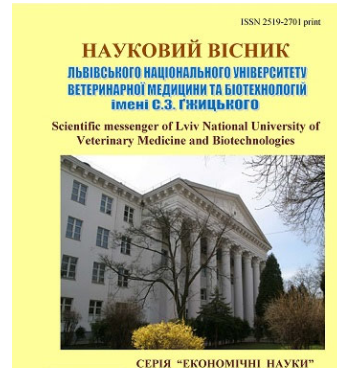 \\ CEPIЯ "ЕКОНОМІЧНI НАУКИ"
SERIES "ЕСONOMICAL SCIENC \\ Том 23 № 97 \\ 2021 \\ Науковий вісник Яьвівського національного університету
ветеринарної медицини та біотехнологій імені С.3. Гжицького. Серія: Економічні науки \\ Scientific Messenger of Lviv National University \\ of Veterinary Medicine and Biotechnologies. \\ Series: Economical Sciences

\section{Features of investment development of agricultural enterprises}

\author{
R. M. Mynivin, V. O. Ivashkiv² \\ ${ }^{1}$ Stepan Gzhytskyi National University of Veterinary Medicine and Biotechnologies Lviv, Lviv, Ukraine \\ ${ }^{2}$ Lviv Polytechnic National University, Lviv, Ukraine
}

Article info

Received 17.09.2021

Received in revised form 18.10.2021

Accepted 19.10.2021

Stepan Gzhytskyi National University of Veterinary Medicine and Biotechnologies Lviv, Pekarska Str., 50, Lviv, 79010, Ukraine. Tel.:+38-050-614-89-82

E-mail:muniv@ukr.net

Lviv Polytechnic National University,

Stepana Bandera Str., 12, Lviv, 79000, Ukraine.

E-mail:

viktoriaivashkiv08@gmail.com
Myniv, R. M., \& Ivashkiv, V. O. (2021). Features of investment development of agricultural enterprises. Scientific Messenger of Lviv National University of Veterinary Medicine and Biotechnologies. Series: Economical Sciences, 23(97), 24-30. doi: 10.32718/nvlvet-e9705

Investments in agricultural enterprises affect the volume of national GDP. At the same time, the development of the investment process in agriculture can have a significant synergistic effect, as investments belong to the gross accumulation of capital, which is one of the components of GDP. Real investment inflows to enterprises in the agro-industrial complex during 2015-2019 tended to increase. In 2019, compared to 2015, the volume of total capital investment in agriculture, forestry and fisheries increased by UAH 28.975 million or $196 \%$, which is a favorable condition for the development of domestic agricultural enterprises. During 2015-2020, there is a positive increase in capital investment in Ukraine's economy as a whole, but the share of capital investment in agriculture tends to decline annually, especially in 2020 compared to 2019, by $17 \%$. The decline in investment activity in agriculture is due to unstable macroeconomic and political factors in our country, limited purchasing power, the beginning of the global economic crisis, the gradual devaluation of the national currency, low efficiency of the agricultural sector. The volume of investment averages about $10 \%$ of the total amount of capital investment in the country is quite low, despite the fact that the agricultural sector of our country has a fairly high potential for development and significant investment attractiveness. The dynamics of the share of investment in the national GDP and gross investment in the economy of Ukraine is characterized by a positive trend towards gradual growth during 2015-2019. In 2010, the volume of investments in the agricultural sector amounted to $1.5 \%$ of GDP of our country and $3.3 \%$ relative to gross investment, and in 2015 these figures were $2.3 \%$ and $3.5 \%$, respectively. In 2019, these figures were $1.7 \%$ and $4.8 \%$. That is, we can state that during the analyzed period there is an increase in the role of investment in the agricultural sector of the economy and in the formation of sustainable economic development potential of Ukraine. According to the results of 2018, agricultural enterprises and organizations of all forms of ownership at the expense of all sources of funding mastered 64 billion UAH. capital investment, which is $127 \%$ compared to the period of 2017 and $340 \%$ compared to 2013. In 2014-2015, there was a decrease in investment activity in the agricultural sector due to the economic crisis in the country. In 2019-2020, the volume of capital investment in agricultural enterprises decreased by UAH 11 billion, which is a sign of deteriorating investment activity in the agricultural sector.

Key words: investments, agricultural enterprises, volumes of investments.

\section{Особливості інвестиційного розвитку аграрних підприємств}

\author{
Р.М. Минів ${ }^{1}$, В. О. Івашків ${ }^{2}$ \\ ${ }^{1}$ Львівський національний університет ветеринарної медицини та біотехнологій імені С. 3. Гљсицького, м. Львів, \\ Україна \\ ${ }^{2}$ Національний університет «Львівська політехніка», м. Львів, Украӥна
}

Інвестииії в підприємства АПК впливають на обсяги формування національного ВВП. При цзому розвиток інвестиційного процесу в сільському господарстві може мати суттєвий синергетичний ефект, адже інвестиції належать до валового накопичення капіталу, щзо є однією зі складових ВВП. 
Реальні інвестичійні надходження до підприємств галузі АПК впродовж 2015-2019 років мали тендениію до збільшення. У 2019 році, в порівнянні з 2015 роком обсяг загальних капітальних інвестицій в сільське, лісове та рибне господарство збільшилась на 28975 млн грн або $196 \%$, шо є сприятливою умовою для розвитку вітчизняних аграрних підприємств. Протягом 2015-2020 років спостерігається позитивне зростання величини капітальних інвестицій в економіку Украӥни в цілому, але частка обсягу капітальних вкладень у галузь сільського господарства має тендениію до щорічного скорочення, особливо ие проявилося у 2020 рочі у порівнянні з обсягами 2019 року, більше на $17 \%$ Зниження активності інвестиційної діяльності в сфери сільського господарства пояснюється нестабільними чинниками макроекономічного та політичного стану намої краӥни, обмеженням купівельної спроможності населення, початком глобальної світової економічної кризи, поступовою девальвацією національної валюти, низькими показниками ефективності аграрного сектору. Обсяги інвестування у середньому близько 10\% від загальної суми капітальних інвестицій по крайні є досить низьким, незважаючи на те, щу аграрний сектор нашої держави має досить високий потенціал для розвитку та значну інвестиційну привабливість. Динаміка частки обсягу інвестицій у національному ВВП та валових інвестиціях в економіці України характеризується позитивною тенденцією до поступового зростання впродовж 2015-2019 років. У 2010 роиі обсяги інвестииій в аграрному секторі склали 1,5\% від ВВП нашої держави та 3,3\% відносно величини валових інвестицій, а у 2015 році изі показники становили відповідно 2,3\% та 3,5\%. У 2019 році цүі показники склали 1,7 \% та 4,8 \%. Тобто, можемо констатувати, щзо протягом аналізованого періоду відмічається зростання ролі інвестицій в аграрний сектор економіки та у формуванні сталого економічного потенціалу розвитку Украӥни. За результатами 2018 року аграрні підприємства та організаціі усіх форм власності за рахунок усіх джерел фінансування освоїли 64 млрд. грн. капітальних інвестицій, ше становить 127 \% відповідного до періоду 2017 року та 340 \% відповідно до 2013 року. У 2014-2015 років спостерігається зменшення обсягів інвестиційної діяльності в аграрному секторі через економічну кризу в країні. У 2019-2020 років обсяги освоєння капітальних інвестицій в аграрних підприємствах знизилися на 11 млрд. грн., щуо є ознакою погіршення інвестиційної активності в агросфері.

Ключові слова: інвестиції, аграрні підприємства, обсяги інвестування.

\section{Вступ}

В умовах економічної глобалізації підвищення рівня інвестиційного забезпечення аграрних підприємств сприяє нарощуванню обсягів виробництва продукції та поліпшенню іiї якості, зростанню їх результативності, отриманню конкурентних переваг на міжнародному ринку та зміцненню продовольчої безпеки держави. Відомо, що сфера агробізнесу приваблива для інвесторів, оскільки на аграрну продукцію завжди $\epsilon$ стійкий попит, який має позитивну динаміку до зростання.

Інвестиції - основа для забезпечення конкурентоспроможності українських агровиробників на міжнародних ринках, важлива передумова успішної інтеграції аграрних підприємств України у світовий економічний простір, підвищення якісних і кількісних показників господарської діяльності як на макро-, так і мікрорівнях та досягнення високого життєвого рівня сільського населення й розвитку сільських територій.

Сьогодні невід'ємною складовою системи заходів iз інвестиційного забезпечення аграрних підприємств повинна стати держава, оскільки ці господарства суттєво залежить від ринкової кон'юнктури і цінової політики, погодно-кліматичних умов, а також багатьох інших чинників ендогенного та екзогенного характеру впливу.

Дослідженню окремих аспектів інвестиційної діяльності в аграрній сфері присвячені праці багатьох вітчизняних вчених, серед яких: М. Д. Бабенко, Л. М. Васильева, I. М. Вахович, Н. В. Данік, Г. Л. Денисюк, О. Ю. Срмаков, М. І. Кісіль, Р. І. Лопатюк та ін. Ці автори здійснили вагомий внесок у розвиток теоретичних та прикладних питань в галузі інвестиційної діяльності аграрних підприємств.

Мета дослідження полягає у виявленні особливостей інвестиційного розвитку аграрних підприємств, формуванню пріоритетів їх інвестиційного розвитку, оцінці інвестиційних надходжень до підприємств галузі АПК та визначення основних факторів, що впливають на активність вітчизняних й іноземних інвесторів стосовно аграрних підприємств України.

\section{Матеріал і методи досліджень}

Для вивчення проблематики та пошуку шляхів іiі розв'язання використано загальні наукові методи абстрагування, аналізу та синтезу. Для здійснення якісного аналізу динамічних економічних процесів застосовано кількісні методи економічної статистики, порівняння, табличного і графічного моделювання. Абстрактно-логічний метод теоретичних та фактичних узагальнень використано для формулювання висновків та пропозицій. Інформаційну базу дослідження склали статистична інформація Державної служби статистики України та наукові статті за розглянутою темою досліджень.

\section{Результати та їх обговорення}

Визначення інвестиційної привабливості є найважливішим і найскладнішим етапом доінвестиційних досліджень. Від того наскільки об'єктивно і всесторонньо здійснена ця оцінка, а отже, й правильно визначені подальші дії щодо того чи іншого проекту, залежать терміни повернення інвестованих коштів. В свою чергу об'єктивність і всебічність забезпечують сучасні методи здійснення оцінки ефективності інвестиційних проектів (Myniv, 2019). Враховуючи світовий досвід можна формувати пріоритети інвестиційного розвитку вітчизняних аграрних підприємств та здійснювати його за відповідними напрямами (рис. 1).

Успішність інвестиційного забезпечення залежить від вдалого поєднання інфраструктури для інвестицій та створення іміджевої складової аграрного бізнесу, формування точок зростання, що є привабливими для інвесторів, усунення гальмівних моментів у регулюванні взаємодії інвесторів та українських компаній. 


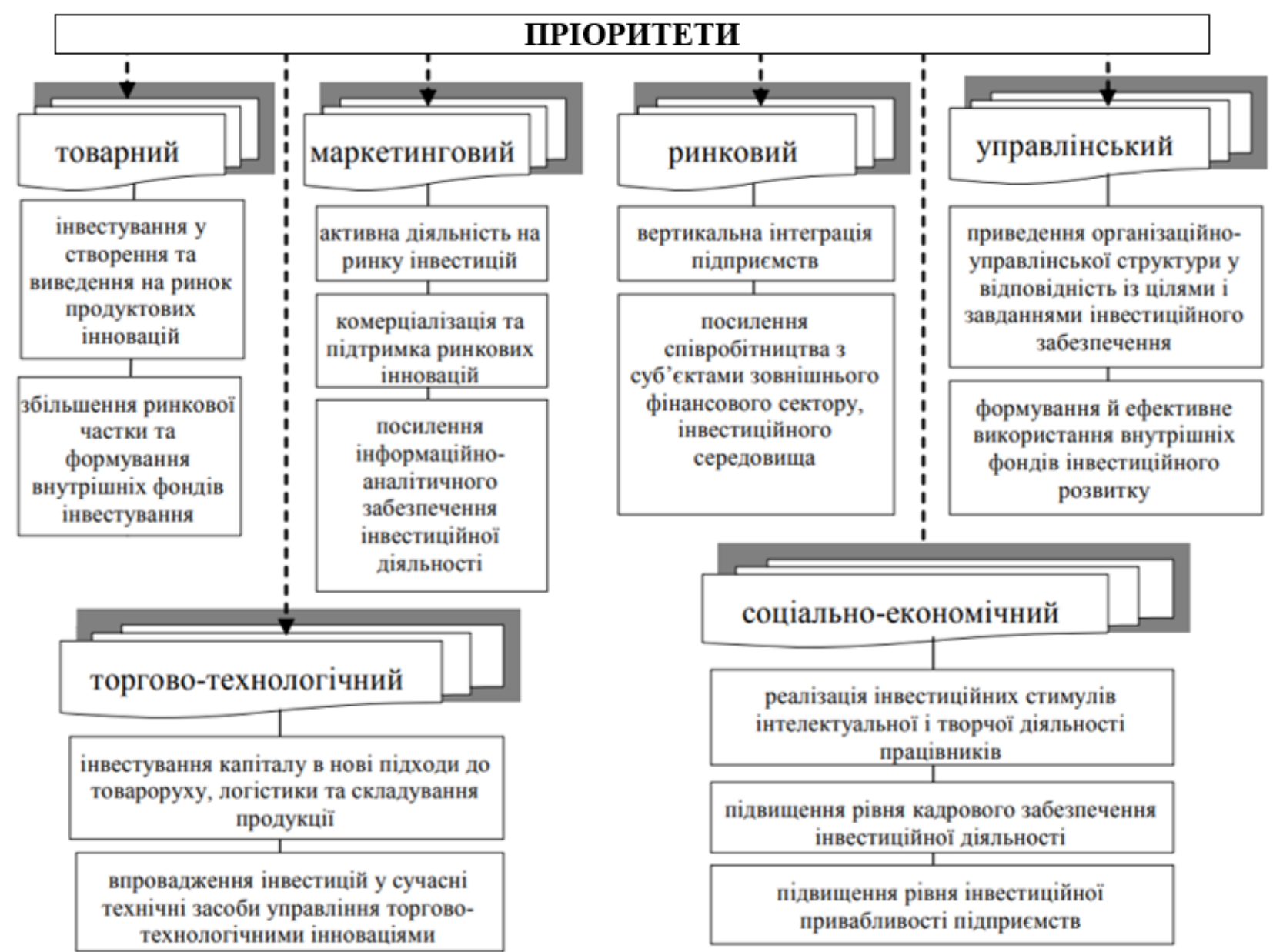

Джерело: власні дослідження

Основними мотиваторами агроінвестицій є: бажання доступу до найкращих ділянок землі, підвищення капіталізації, диверсифікація інвестиційного портфелю за рахунок вкладень в аграрний сектор за зниження віддачі від інших секторів тощо. Водночас важливою $є$ роль держави в регулюванні відносин у інвестиційному середовищі, яке характеризується нерівністю доступу аграрних підприємств до ринків, кредитних ресурсів, інновацій та технологій (Kyrylov, \& Hranovska, 2019).

Проводячи оцінку розвитку інвестиційної діяльності в сільському господарстві можемо проаналізувати динаміку інтенсивності інвестування в галузь сільського господарства (табл. 1).

\section{Таблиця 1}

Прямі інвестиції (акціонерний капітал) в економіці України за видами економічної діяльності*

\begin{tabular}{lccccccc}
\hline & Код за & \multicolumn{5}{c}{ Обсяги станом на 1 січня, млн. дол. США } \\
\cline { 3 - 7 } & КВЕД & 2015 & 2016 & 2017 & 2018 & 2019 & 2020 \\
\hline Усьго & & 53704 & 40725 & 36155 & 37513 & 32905 & 35810 \\
Сільське, лісове та рибне господарство & А & 776,9 & 617,0 & 502,2 & 586,2 & 451,9 & 542,1 \\
\hline
\end{tabular}

*Без урахування тимчасово окупованої території Автономної Республіки Крим і м.Севастополя, також без частини зони проведення антитерористичної операції;

Джерело: розраховано за матеріалами офіційних даних (Derzhavna Sluzhba Statystyky..., 2021)

У сучасних умовах господарювання аграрні підприємства потребують великих капітальних вкладень для накопичення доходу від своєї діяльності за такими ключовими напрямами: введення в дію приміщень тваринницьких, будівництво теплиць закритого грунту, будівництво оптово-роздрібних ринків продукції сільськогосподарської, рекультивація земель, будівництво заводів 3 альтернативних видів палива, будівництво елеваторів, будівництво комбікормових, силосних i сінажних споруд та ін. (Masiuk, 2021).

Реальні інвестиційні надходження до підприємств галузі АПК впродовж 2015-2019 років мали тенденцію до збільшення. У 2019 році, в порівнянні з 2015 роком обсяг загальних капітальних інвестицій в сільське, лісове та рибне господарство збільшилась на 28975 млн грн або $196 \%$, що є сприятливою умовою для розвитку вітчизняних аграрних підприємств (табл. 2). 
Таблиця 2

Капітальні інвестиції за видами економічної діяльності

\begin{tabular}{|c|c|c|c|c|c|c|}
\hline & \multicolumn{6}{|c|}{ Обсяги станом на 1 січня, млн.грн } \\
\hline & 2015 & 2016 & 2017 & 2018 & 2019 & 2020 \\
\hline Усьго & 219419 & 273116 & 359216 & 448461 & 578726 & 602325 \\
\hline $\begin{array}{l}\text { Сільське господарство, лісове } \\
\text { господарство та рибне господарство }\end{array}$ & 18797 & 30155 & 50484 & 64243 & 65901 & 55254 \\
\hline $\begin{array}{l}\text { Сільське господарство, мисливство та } \\
\text { надання пов'язаних із ними послуг }\end{array}$ & 18388 & 29310 & 49660 & 63401 & 65037 & 54529 \\
\hline Лісове господарство та лісозаготівлі & 381 & 788 & 777 & 769 & 789 & 661 \\
\hline Рибне господарство & 27 & 57 & 47 & 74 & 76 & 63 \\
\hline $\begin{array}{l}\text { Питома вага інвестицій у сільське } \\
\text { господарство, \% }\end{array}$ & 9,8 & 10,6 & 13,8 & 14,0 & 11,3 & 9,4 \\
\hline $\begin{array}{l}\text { Темп приросту інвестицій у сільське } \\
\text { господарство, \% }\end{array}$ & 183,6 & 270,8 & 169,5 & 127,6 & 102,7 & 85,0 \\
\hline
\end{tabular}

Джерело: розраховано за матеріалами офіційних даних (Derzhavna Sluzhba Statystyky..., 2021)

Протягом 2015-2020 років спостерігається позитивне зростання величини капітальних інвестицій в економіку України в цілому, але частка обсягу капітальних вкладень у галузь сільського господарства має тенденцію до щорічного скорочення, особливо це проявилося у 2020 році у порівнянні з обсягами 2019 року, більше на $17 \%$.

Зниження активності інвестиційної діяльності в сфери сільського господарства пояснюється нестабільними чинниками макроекономічного та політично- го стану нашої країни, обмеженням купівельної спроможності населення, початком глобальної світової економічної кризи, поступовою девальвацією національної валюти, низькими показниками ефективності аграрного сектору. Обсяги інвестування у середньому близько 10 \% від загальної суми капітальних інвестицій по країні є досить низьким, незважаючи на те, що аграрний сектор нашої держави має досить високий потенціал для розвитку та значну інвестиційну привабливість.

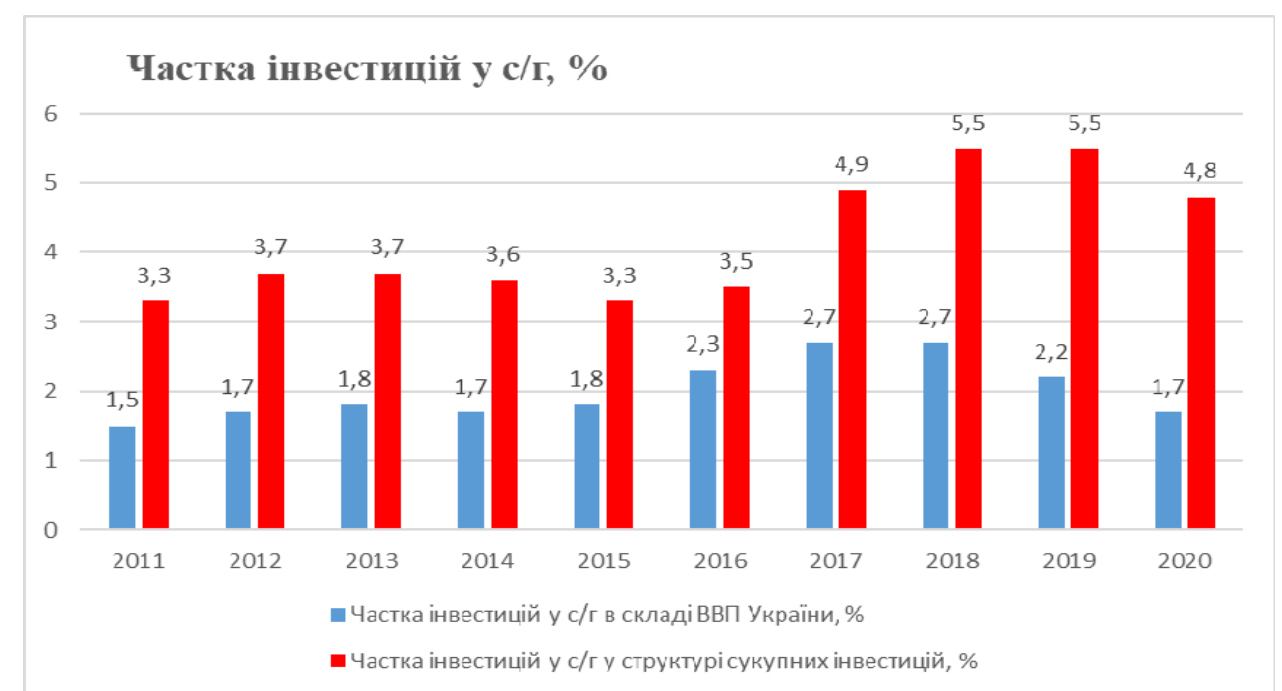

Рис. 2. Частка інвестицій у сільському господарстві відносно ВВП та валових інвестицій в економіці України Джерело: розраховано та побудовано за матеріалами офіційних даних (Derzhavna Sluzhba Statystyky..., 2021)

За підсумками досліджень вчених Інституту аграрної економіки: “у 2020 році обсяги капітальних інвестицій в агропромислові сектори економіки України склали 36 млрд грн, капіталовкладення в агропромислові сектори економіки минулого року суттєво скоротилися і склали лише 53,3 \% відповідного показника 2019 року. Індекси обсягів цих капітальних інвестицій за січень - грудень 2020 року до відповідного періоду попереднього року становлять по сільському господарству $54,7 \%$, лісовому господарству $-65,5 \%$, рибному господарству $-53,6 \%$, а також харчовій промисловості - 51,5\%”. Ці показники свідчать, що у 2020 році у агропродовольчих секторах економіки відбула- ся інвестиційна криза, глибина якої зіставна з 2009 роком, коли в умовах світової фінансової кризи капітальні інвестиції у сільське господарство України скоротилися більш ніж наполовину. Інвестиційний спад по сільському господарству і харчовій промисловості в 2020 році був глибшим, ніж в інших сектоpax економіки, по яких індекс капітальних інвестицій склав $62,8 \%$. Це означає, що відносини між видами економічної діяльності в економіці України торік змінювалися не на користь іiі агропродовольчих секторів. Інвестиційна криза у сільському господарстві у 2020 році супроводжувалася скороченням обсягів виробництва сільськогосподарської продукції (мінус 
11,5\%) і цін на неї (мінус 11,6 \%) (U 2020 rotsi v ahroprodovolchykh..., 2021).

Інвестиції в підприємства АПК впливають на обсяги формування національного ВВП. При цьому розвиток інвестиційного процесу в сільському господарстві може мати суттєвий синергетичний ефект, адже інвестиції належать до валового накопичення капіталу, що є однією зі складових ВВП. Динаміку обсягів частки інвестицій у сільському господарстві в складі вітчизняного ВВП та у складі сукупних інвестицій в економіці України наведено на рис. 2.

Динаміка частки обсягу інвестицій у національному ВВП та валових інвестиціях в економіці України характеризується позитивною тенденцією до посту- пового зростання впродовж 2015-2019 років. У 2010 році обсяги інвестицій в аграрному секторі склали 1,5\% від ВВП нашої держави та 3,3 \% відносно величини валових інвестицій, а у 2015 році ці показники становили відповідно 2,3 \% та 3,5 \%. У 2019 році ці показники склали 1,7 \% та 4,8 \%. Тобто, можемо констатувати, що протягом аналізованого періоду відмічається зростання ролі інвестицій в аграрний сектор економіки та у формуванні сталого економічного потенціалу розвитку України.

Обсяги інвестицій аграрних підприємств впродовж 2011-2020 років у розрахунку на одне господарство та на одного жителя України наведено на рис. 3.

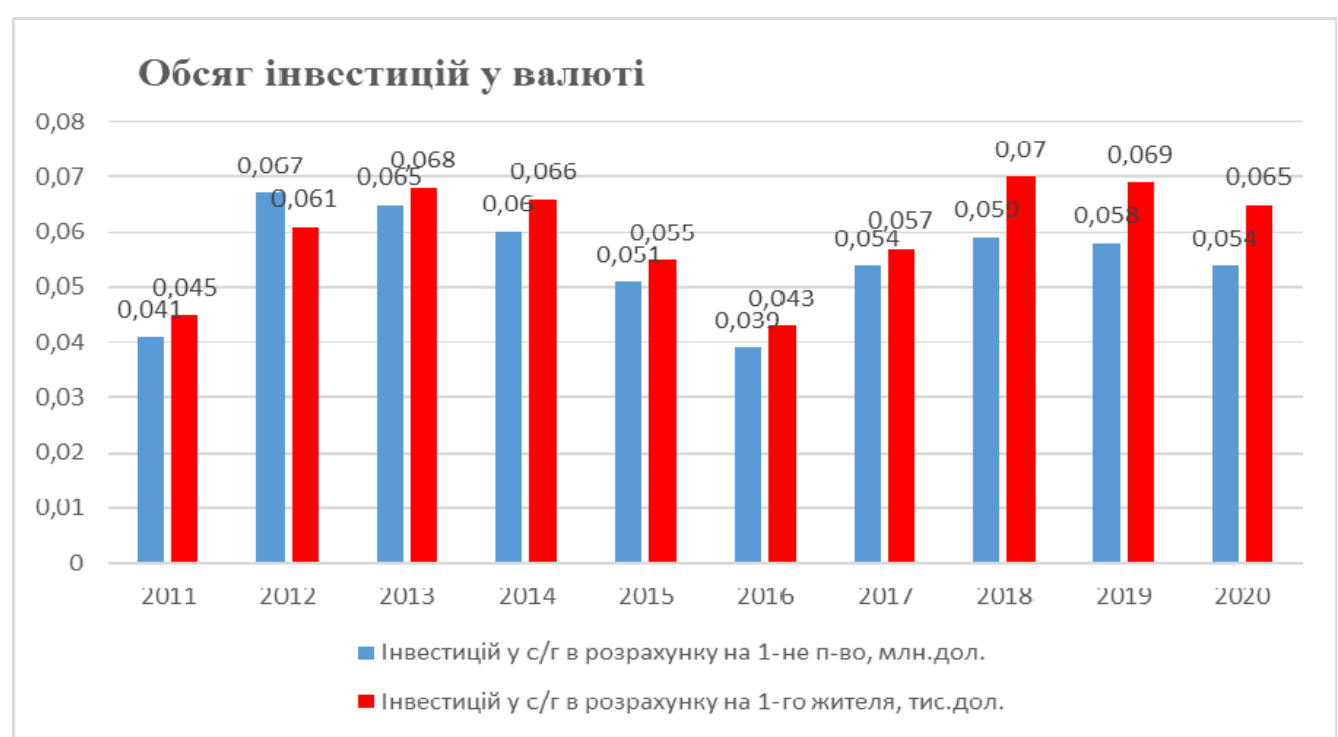

Рис. 3. Динаміка обсягу питомих інвестицій в аграрні підприємства відносно кількості підприємств та чисельності населення України

Джерело: розраховано та побудовано за матеріалами офіційних даних (Derzhavna Sluzhba Statystyky..., 2021)

Динаміка обсягу питомих інвестицій в аграрні підприємства відносно кількості підприємств та чисельності населення України впродовж 2011-2020 років мала нестійку динаміку.

Оскільки інвестиції є основним фактором позитивних зрушень в економіці, то для оцінювання ролі інвестицій у діяльності окремих аграрних підприємств проаналізуємо загальну динаміку капітальних інвестицій в економіці України та їх частку у створенні доданої вартості в аграрному секторі економіки України (рис. 4).

За даними рис. 4, обсяги капітальних інвестицій протягом останнього десятиліття в нашій країні мали позитивну зростаючу тенденцію. За результатами 2018 року аграрні підприємства та організації усіх форм власності за рахунок усіх джерел фінансування освоїли 64 млрд. грн. капітальних інвестицій, що становить $127 \%$ відповідного до періоду 2017 року та $340 \%$ відповідно до 2013 року. У 2014-2015 років спостерігається зменшення обсягів інвестиційної діяльності в аграрному секторі через економічну кризу в країні. У 2019-2020 років обсяги освоєння капітальних інвестицій в аграрних підприємствах знизи- лися на 11 млрд. грн., що є ознакою погіршення інвестиційної активності в агросфері.

На наш погляд основними факторами, що негативно впливають на активність вітчизняних та іноземних інвесторів стосовно аграрних підприємств України, є:

- невизначеність та нестабільність законодавства в сфері аграрного бізнесу;

- відсутність ефективного регулювання цінових відносини між суб`єктами аграрного ринку;

- девальвація національної валюти;

- зниження обсягів прибутку вітчизняних агровиробників через збільшення величини імпорту сільгсппродукції в Україну;

- низька платоспроможність населення та державних підприємств;

- незавершеність інституційних перетворень в аграрному секторі економіки;

- висока вартість кредитних ресурсів;

- недосконала податкова система;

- низький рівень захищеності інвестицій та інвесторів тощо. 


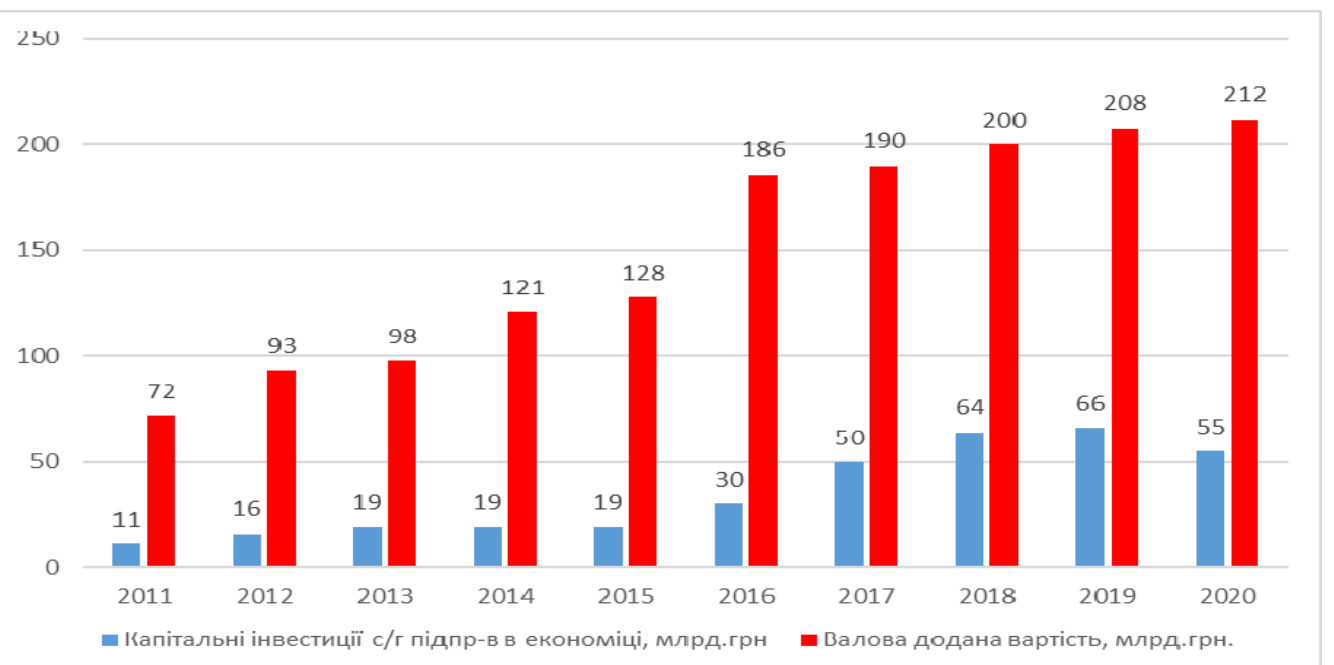

Рис. 4. Динаміка показників капітальних інвестицій підприємств та валової доданої вартості в аграрних підприємствах України, млрд. грн.

Джерело: розраховано та побудовано за матеріалами офіційних даних (Derzhavna Sluzhba Statystyky..., 2021)

\begin{tabular}{|c|}
\hline Основні пріоритети \\
\hline $\begin{array}{l}\text { формувння інфраструктурного забезпечення щодо реалізації продукціі } \\
\text { агропромислового виробннцтва }\end{array}$ \\
\hline $\begin{array}{l}\text { надання виробничих та збутових послуг сільськогосподарськнм та іншим } \\
\text { суб'єктам агропромислового виробннцтва }\end{array}$ \\
\hline $\begin{array}{l}\text { запровадження високо продуктивних та інноваційних технологій по } \\
\text { вирощуванню сільськогосподарських культур та утриманню поголоів галузі } \\
\text { тваринництва }\end{array}$ \\
\hline $\begin{array}{l}\text { створення виробничих потужностей та агросировинної бази для виробництва } \\
\text { допоміжної продукції }\end{array}$ \\
\hline $\begin{array}{l}\text { оновлення та можлнвості модернізації на основі новітніх та інноваційннх } \\
\text { технологій, в перуш чергу, підпрнємств агропродовольчої промисловості, а } \\
\text { також тих суб'єктів бізнесу, що займаються процесами заготівлі та зберігання } \\
\text { сільськогосподарської продукції }\end{array}$ \\
\hline $\begin{array}{l}\text { Захист внутрішніх ринків через нетарифні заходи щодо екологічного та } \\
\text { технічного стану імпортованих товарів }\end{array}$ \\
\hline $\begin{array}{l}\text { розвиток технологій машннобудування та виробництво устаткування для } \\
\text { м'ясомолочної, масложирової, борошномельної, круп'яної та хлібопекарської } \\
\text { промисловостей }\end{array}$ \\
\hline $\begin{array}{l}\text { налагодження внробннцтва ефективних хімічннх засобів захисту рослин і } \\
\text { препаратів для ветеринарної медицнни }\end{array}$ \\
\hline Уникнення викривлень в механізмі ціноутворення продукції на ринках збуту \\
\hline $\begin{array}{l}\text { Виправлення критичних або форс-мажорних ситуацій та забезпечення } \\
\text { національної продовольчої безпеки, ліквідація стихійннх лих тощо }\end{array}$ \\
\hline $\begin{array}{l}\text { Програмн страхування внробників сільськогосподарської продукції та } \\
\text { гарантувати ім певний рівень доходів відповідно до внмог СОТ }\end{array}$ \\
\hline
\end{tabular}

Рис. 5. Елементи комплексної програми інвестиційного забезпечення аграрних підприємств Джерело: власні дослідження

Вирішальним фактором у підвищенні рентабельності та прибутковості аграрних підприємств стає не рівень приросту інвестицій та концентрації капіталу, а їх якісна структура й спрямування ресурсів на запровадження інноваційної моделі розвитку підприємств, підвищення їх ефективності, використання новітніх енергозберігаючих технологій та техніки, інноваційних форм організації праці та науково-обгрунтованої системи менеджменту (Myniv \& Mokrytska, 2020). 
Незважаючи на те, що в нашій країні реорганізовані колективні сільгосппідприємства у нові агроформування, закладені основи суб'єктів приватного господарювання в аграрніи сфері, введені механізми кредитної підтримки аграрних товаровиробників, послаблено податкове навантаження, здіиснюються заходи щодо реалізації ряду державних програм у сфері аграрного виробництва, створені передумови для залучення інвестиціиних ресурсів, аграрні підприємства потребують розробки та впровадження комплексної державної програми інвестиційного забезпечення їх розвитку та посилення конкурентноспроможності на ринку за основними пріоритетними (рис. 5).

Аграрні підприємства нашої держави потребують значного інвестиціиного забезпечення. Необхідно звернути увагу на питання щодо пріоритетності окремих існуючих інвестиційних програм розвитку аграрної галузі. Питання залучення інвестицій у сучасних економічних умовах та їх раціональне використання набуває особливого значення. Для ефективного функціонування аграрних підприємств та виробництва конкурентоспроможної сільськогосподарської продукції потрібні значні обсяги інвестиційних ресурсів, що дозволить агроформуванням вирішити питання оновлення матеріально-технічної бази, запровадити інноваційні ресурсозберігаючі технології, підвищити стійкість виробничих систем, що в комплексі 3 фінансово-економічною підтримкою через фінансово-кредитні інститути покращить інвестиційний клімат та сприятиме розвитку підприємництва на селі й вирішенню проблеми продовольчої безпеки нашої держави.

\section{Висновки}

Аналіз залучення інвестицій аграрними підприємствами свідчать про необхідність перегляду інвестиційної політики з врахуванням особливостей аграрного сектору. Тільки раціональне використання наявних інвестиційних ресурсів та створення сприятливого інвестиційного клімату забезпечить ефективність агроформувань в цілому. Стимулювання розвитку інвестиційних процесів в аграрній сфері має стати одним із пріоритетних завдань 3 вирішення ряду пи- тань на всіх рівнях господарювання. Першочергово необхідно покращити фінансове забезпечення інвестиційної діяльності аграрних підприємств через збільшення обсягів довгострокового кредитування на фоні зменшення обсягів короткострокового використання кредитів та оптимального співвідношення власних та залучених фінансових ресурсів.

Перспективи подальших досліджень. У подальшому планується дослідити взаємозв'язок обсягів інвестиційного забезпечення аграрних підприємств та їх ефективний розвиток.

\section{References}

Derzhavna Sluzhba Statystyky Ukrainy. URL: http://www.ukrstat.gov.ua (in Ukrainian).

Kyrylov, Yu. Ie., \& Hranovska, V. H. (2019). Inves-tytsiinyi mekhanizm zabezpechennia konkurentospromozhnosti ahrarnykh pidpryiemstv. Ekonomika ta derzhava, 12, 1318. doi: 10.32702/23066806.2019.12.13 (in Ukrainian).

Masiuk, Yu. V. (2021). Kliuchovi aspekty investy-tsiinoho zabezpechennia ahrarnykh pidpryyemstv. Ahrosvit, 7-8. 67-71. doi: 10.32702/2306-6792.2021.7-8.67 (in Ukrainian).

U 2020 rotsi v ahroprodovolchykh sektorakh eko-nomiky vidbulasia investytsiina kryza, hlybyna yakoi spivstavna z 2009 rokom. NNTs "IAE": vebsait. URL: http://www.iae.org.ua/presscentre/archnews/3056 (data zvernennia: 15.09.2021) (in Ukrainian).

Myniv, R. M. (2019). Metodychni pidkhody do otsi-nky investytsiinoi pryvablyvosti silskohospodarskykh pidpryiemstv Naukovyi visnyk LNUVMB imeni S.Z. Hzhytskoho "Ekonomichni nauky", 21(93), 63-69. doi: 10.32718/nvlvet-e9313 (in Ukrainian).

Myniv, R. M., \& Mokrytska, H. M. (2020). Investy-tsiine zabezpechennia efektyvnoho rozvytku pidpry-yemstv APK Lvivskoi oblasti. Naukovyi visnyk LNUVMB imeni S. Z. Hzhytskoho. "Ekonomichni nauky", 22(96), 28-34. doi: 10.32718/nvlvet-e9605. (in Ukrainian).

Tkachenko, S. V. (2021). Analiz investytsiinoi diyalnosti $\mathrm{v}$ ahrarnomu sektori Ukrainy, vyznachennia faktoriv ta shliakhiv yii aktyvizatsii. Ekonomika ta suspilstvo. Vypusk, 23. doi: 10.32782/2524-0072/2021-23-3 (in Ukrainian). 